\title{
Patent Protection and Atomic Energy Legislation
}

\author{
Stefan A. Riesenfeld*
}

I

THE PATENT PROVISIONS OF THE ATOMIC ENERGY ACT OF 1954

\section{A. Background and Battleground}

\section{Genesis and Content of the Patent Provisions in the 1946 Act}

When the release of atomic energy, whether by fission or fusion, ceased to be a purely military matter ${ }^{1}$ and emerged as the most promising avenue for peaceful human progress, it became clear that a new and bold legislative policy governing the production and utilization of the new power source had to be shaped. It was felt that, at least at the beginning, the government would still liave to bear the brunt of the development and retain vast monopoly and control powers in order to assure that scientific and technical endeavors would not slacken and that national security would not be imperiled; after a heated and crucial battle, it was settled that a new civilian agency should be the center of the new governmental activities. ${ }^{2}$

It soon became evident that the government's special position and responsibility in the atomic energy field would have important patent implications and require special regulation. ${ }^{3}$ To be sure, the first bill on the control of atomic energy, ${ }^{4}$ introduced by the late Senator McMahon, the pioneer of the new legislation, contained no mention of patent questions. But his second bill which was introduced shortly before the end of $1945^{\mathrm{B}}$ incorporated some important provisions to this effect.

The new bill singled out and differentiated two types of inventions: (1) those of "a device or method for the production, refining or other processing

* Professor of Law, University of California. The views expressed in this article are strictly the personal opinions of the author and in no way refiect any position of the Regents of the University of California, a prime contractor of the AEC.

1 About the military plrase of the development of release and utilization of nuclear energy, see particularly SMrte, Atomic Energy for MitTtary Purposes (1946).

2 About the history of the first atomic energy legislation, see especially Miller, $A$ Law Is Passed-The Atomic Energy Act of 1946, 15 U. CHr. I. REv. 799 (1948).

3 About the handling of the patent aspects of inventions relating to atomic energy development during the military control phase, see Newman \& Miller, Patents and Atomic Energy, 12 LAW \& CONTEMP. PROB. 746 (1947).

4S. 1359, 79th Cong., 1st Sess. (1945).

5S. 1717, 79th Cong., 1st Sess. (Dec. 20, 1945). For the text of the bill see also Atomic Energy Act of 1946, Hearings before Senate Special Committee on Atomic Energy on S. 1717, 79th Cong., 2d Sess. 1 (1946). 
of fissionable material" and (2) those of "any process or device utilizing or peculiarly necessary to the utilization of fissionable materials, or peculiarly necessary to the conduct of research or developmental activities in the [atomic] fields" (as specified in the bill). For the first class of inventions patents were to be issued or, if already issued, to be assigned to the Commission subject to a right to fair compensation of the inventor. The second class of inventions was left to privately-owned patents, but declared to be affected with a public interest and made generally available upon payment of a reasonable royalty fee. ${ }^{6}$ In the course of the hearings on the bill before the Senate Special Committee on Atomic Energy ${ }^{7}$ the proposed patent provisions drew a considerable amount of attention. Henry Wallace, then Secretary of Commerce, urged important changes in three respects. ${ }^{8}$ In the first place he argued that the patent system had no raison d'être with respect to inventions in those fields of activity which the government reserved exclusively to itself. Second, he maintained that the government or the public at large should obtain patent rights to all other inventions stemming from publicly financed research. Lastly, he recommended certain restrictions of the compulsory licensing provisions. His argnments seem to have been persuasive to a large extent. As a result of them the Committee rewrote the patent provisions as well as most other sections of the bill and recommended its passage in its redrafted form. ${ }^{9}$

The new patent section, section 11 of the bill, ${ }^{10}$ made a number of important structural changes in the existing patent system:

(1) Patent protection was withdrawn, both prospectively and retrospectively, for certain critical areas of technology and against certain privileged practices of inventions.

(a) Patentability was abolished in toto for inventions useful solely in the production of fissionable material or in the utilization of fissionable material or atomic energy for a military weapon. ${ }^{11}$

(b) Patent coverage was excluded for other inventions to the extent that they are used in the production of fissionable material or in the utilization of fissionable material or atomic energy for a military weapon. ${ }^{13}$

${ }^{6}$ S. 1717, 79th Cong., 1st Sess., $\$ 10$. See also the summary given by one of the draftsmen of the bill, Miller, A Law Is Passed-The Atomic Energy Act of 1946, 15 U. CEI. L. Rev. 799, 808 (1948).

7 Atomic Energy Act of 1946, Hearings before Senate Special Committee on Atomic Energy on S. 1717, 79th Cong., 2d Sess. (5 parts) (1946).

8 Id. at $225-26$.

${ }^{9}$ Atomic Energy Act of 1946, S. REp. No. 1211, 79th Cong., 2d Sess. 1 (1946).

10 Id. at 24.

11 S. 1717 (Special Committee Draft), 79th Cong., 2d Sess., §11(a) (1) (1946).

12 Id. § 11(a) (2). 
(c) Patent protection was likewise eliminated for other inventions to the extent that they are used in the conduct of research and development activities in certain atomic fields catalogued by the bill. ${ }^{13}$

(2) Broad powers of eminent domain were specifically accorded to the federal government, represented by an Atomic Energy Commission, with respect to inventions-whether or not covered by patents or pending applications-which are useful in the production of fissionable material or in the utilization of fissionable material or atomic energy for military weapons, or which utilize or are essential in the utilization of fissionable material or atomic energy. ${ }^{14}$

(3) The Commission was empowered to declare any patent, regardless of private ownership, to be affected with a public interest and as a result subject to certain broad but non-gratuitous licenses if the invention covered by the patent utilized, or was essential to the utilization of, fissionable material or atomic energy and, moreover, such licensing was necessary to effectuate the statutory policies and purposes. Such compulsory licenses authorized practicing of the invention in question, both by the Commission itself and by all private operators holding licenses to carry out the manufacturing or utilization activities subjected to such control by the bill. ${ }^{15}$

This triple regime of limited or non-patentability, government acquisition through condemnation and compulsory licensing was implemented by a congeries of provisions desigued to assure prompt and adequate government information of inventions thus given a special status and to accord appropriate compensation or fair reward to persons affected by the new arrangement:

(1) The bill imposed a duty of prompt and complete disclosure on all makers of inventions useful in the production of fissionable material or in the utilization of fissionable material or atomic energy for military weapons. ${ }^{16}$ In addition it obligated the Commissioner of Patents to notify the Atomic Energy Commission of all patent applications covering such or other inventions subject to the new powers of eminent domain. ${ }^{17}$

(2) In order to secure just compensation or reasonable royalty fees to patent owners subjected to withdrawal of acquired patent protection, condemnation and requisition, or compulsory licensing, as well as to provide fair rewards as an incentive to inventors affected by the exemptions from patentability, a special Patent Compensation Board to be designated by the Commission was created. The bill contained fairly detailed standards for

\footnotetext{
$13 I d . \$ 11(b)$.

$14 I d . \$ 11(\mathrm{~d})$.

$15 I d . \$ 11(c)(1)$ and (2).

${ }^{16}$ Id. \&11(a) (3).

17 Id. \& 11(d), last clause.
} 
the determinations to be made by the board and provided for judicial review thereof upon petition by the aggrieved party. ${ }^{18}$

These provisions of the revised bill had smooth sailing in the Senate ${ }^{19}$ but met with violent criticism in the House of Representatives ${ }^{20}$ and were finally struck out and replaced by a different system proposed by Congressman Lanham. ${ }^{21}$ However, they prevailed in the Conference ${ }^{22}$ and were translated into law by the Atomic Energy Act of $1946 .^{23}$

\section{From the Atomic Energy Act of 1946 to the Revision of 1954}

In spite of the turbulent circumstances of their birth and certain flaws in their draftsmanship the patent provisions of the 1946 Act did not hurl their administration into a chasm. The AEC went to work quietly and tackled its task methodically and with circumspection. In January 1947 it appointed a Patent Advisory Panel "to recommend to the Commission policies, procedures and staff organization for the effectuation of the patent provisions of the Act"24 and, upon submission of its report on September 17, $1947^{25}$ and after proper hearing, promulgated the admimstrative rules governing proceedings for compensation, royalty fees and incentive awards. ${ }^{28}$ The Patent Compensation Board was appointed in April of $1949^{27}$ and since that date has processed a dozen or so cases. A few of the applications

18 Id. $\S \S 11$ (e) and 13. For a discussion and construction of the judicial review provisions after they bccame law see Fletcher v. U.S. Atomic Energy Comm'n, 192 F.2d 29 (D.C. Cir. 1951).

1092 CoNG. Rec. 6076-98 (1946).

20 Id. at $9249-75,9340-86,9464-77,9545-63$ (1946).

21 Id. at $9484-93,9561$ (1946).

22 Atomic Energy Act of 1946, Conference Report to Accompany S. 1717, H.R. REP. No. 2670, 79th Cong., 2d Sess. 10-12 (1946).

23 C. 724, $\$ \S 11,13,60$ StaT. 768, 772, 42 U.S.C.A. $\$ \S 1811,1813$ (1952). For detailed discussions of the former law see especially Boskey, Inventions and the Atom, 50 CoLuM. L. REv. 433 (1950) ; Danl \& Brown, Domestic Control of Atomar Energy 69 (Social Science Research Council Pamphlet No. 8 (1951) ; Newman \& Miller, Patents and Atomic Energy, 12 Law \& Contearp. Prob. 746 (1947), reprinted in Newaran \& Murer, The Control of Atonfc Energy 142 (1948); Ooms, Atomic Energy and U.S. Patent Policy, 2 BuLL. OF the Atonnc Screntists, No. 9 and 10, at 28, No. 11 and 12, at 30 (1946); Ooms, The Patent Provisions of the Atomic Energy Act, 15 U. CHI. L. Rev. 822 (1948); Ooms, Problems of Patent Policy for Government and Industry in Atomic Energy, LECTURES ON ATONIC ENERG INDUSTRIAL AND Iregar Problems 155 (U. of Mich. 1952); Note, Atomic Energy Patent Provisions and the American Economy, 97 U. PA. L. Rev. 389 (1949).

24 AEC, First Semiannual Report, S. Doc. No. 8, 80th Cong., 1st Sess. 10 (1947); AEC, Second Semiannual Report, S. DGc. No. 96, 80th Cong., 1st Sess. 17 (1947).

25 AEC, Third Semiannual Report, S. Doc. No. 118, 80th Cong., 2d Sess. 35 (1948) ; AEC, Fifre SeMtanNuat Report 149 (1949).

26 The regulations were published in the proposed form on May 8, 1948, 13 FED. REg. 2487 and promulgated in their final form on June 24, 1948, 13 FED. REg. 3457, 10 C.F.R. pt. 80 (1949); of. AEC, Fourth Semtannoar Report 57 (1948); AEC, Fifte Semtannoar Report 149, 173 (1949).

27 AEC, Sixth SentanNoat Report 14 (1949). 
were terminated by sizable settlements, ${ }^{28}$ one led to an award of $\$ 7,500$ in favor of the applicant, ${ }^{29}$ but the majority were rejected. ${ }^{30}$

The Commission saw no occasion to exercise its statutory authority to declare patents affected with public interest and thereby subject them to automatic licenses. Following the lines of action recommended by the initial report of the Patent Advisory Panel, the AEC looked at its authority in this respect as a "reserve power" to be exercised only "under certain rather exceptional circumstances."31 The successful maintenance of this position rested principally upon the practice followed by the AEC of reserving to itself the right to take title to any invention made in the course of work under the research, development and operations contracts concluded by it and supported with public funds. In execution of this approach the Commission developed three types of patent clauses-designated "type A," "type B" and "type C" - which were inserted in the contracts according to what kind of work by the contractor was involved. Type A, the most sweeping and most commonly used, accorded the Commission the power to insist on acquisition of full patent riglits, while types $B$ and $C$ left the contractor's rights as non-exclusive and sole licensee, respectively, in fields other than atomic energy. ${ }^{32}$ Because of the rapidly mounting patent portfolio thus accumulating, in December 1949 the AEC initiated a program offering and

${ }^{28}$ Application of Clristofilos ( $\$ 10,000$ settlement) ; Application of Giannini \& Co., involving the basic Fermi-Pontecorvo patent for production of radioactive substances by means of neutron moderation ( $\$ 300,000$ settlement); Application of Seaborg, Kennedy, Wall \& Segre (\$400,000 settlement). See AEC, Fifteentr Semaannual Report 52 (1954); AEC, E1GHT-

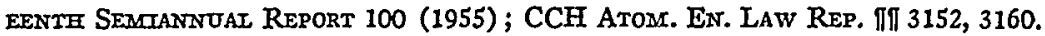

29 In re McClellan, 91 U.S.P.Q. 278 (1951), CCH Atom. EN. LAw REP. I 3154; see also AEC, Exeventr Sematanvoni Report 44 (1952); Ooms, Problems of Patent Policy for Government and Industry in Atomic Energy, Lectures on Atomic ENERgy IndUSTRIAL aNd LEGAT Probiemss 155, 185 (U. of Mich. 1952).

30 In re Fletcher, 84 U.S.P.Q. 386 (1950), CCH ATOM. EN. LAW REP. $\| 3151$, aff'd sibb nom. Fletcher v. AEC, 192 F.2d 29, 90 U.S.P.Q. 3 (D.C. Cir. 1951) [for a connected phase of the litigation see Fletcher v. United States, $133 \mathrm{Ct}$. Cl. 896, CCH ATOM. EN. LAW REP. $\{3303$ (1956)]; In re Pacyna, 89 U.S.P.Q. 196, CCH Arom. Ev. LaW Rep. $\int 3153$ (1951); In re Schulz, 94 U.S.P.Q. 124, CCH ATOM. Ev. LAW REP. I 3155 (1952); In re Fulmer, CCH Atom. EN. Law Rep. $\{3156$ (1950); In re Matheson, CCH Atom. EN. Law Rep. $\llbracket 3157$ (1951); In re Lindequist, 88 U.S.P.Q. $264, C C H$ ATOM. EN. LAw REp. $\lceil 3158$ (1951); In re Rapp, 105 U.S.P. Q. 48, CCH ATOM. EN. LAW REP. $\int 3159$ (1955); In re Grossman, 107 U.S.P.Q. 181, CCH Atom. EN. LAW REP. $\int 3161$ (1955) (on remand by D.C. Cir.) 111 U.S.P.Q. 388, CCH Atom. EN. LAw REP. $\| 3163$ (1956), aff'd sub nom. Grossman v. United States, CCH ATOM. EN. LAW REp. $\llbracket 3305$ (D.C.Cir. 1957); In re Dittenleimer, 109 U.S.P.Q. 259, CCH AToM. EN. LAW REP. $\Uparrow 3162$ (1956).

31 AEC, Fitre Seamannuar Report 148 (1949).

32 For a brief summary of the content of the three types of patent clauses and the field of their application, see AEC, FIFTH SEMCANNOAI REPoRT 150 (1949) ; DAEL \& Brown, DoMESTIC CONTRot of ATOMrc Energy 73 (Social Science Research Council Pamphlet No. 8 (1951)). Inventions made in the course of work (not financed by the Commission) on or with radioactive isotope compounds obtained from the Commission were left to unrestricted private patent rights, AEC, FIFTE SEMTANNUAL REPORT 151 (1949). 
freely granting licenses on a royalty-free, non-exclusive basis for patents acquired by it as a result of inventions made by AEC personnel or contractor employees on AEC work. ${ }^{33}$ The AEC thus successfully avoided becoming embroiled in cumbersome controversies and the very few court decisions which were rendered ${ }^{34}$ caused no special difficulties.

\section{The Revision of 1954: New Tempest in a Teapot}

Toward the end of 1952, at the latest, it became evident that the 1946 legislation no longer corresponded to the "nuclear realities" 35 of the times. The atomic energy monopoly of the United States had vanished in 1949 when the USSR exploded her first atomic bomb; the advances in the art of harnessing atomic energy for peaceful uses had been made at such a pace that the further development of the nuclear reactor program made broadened participation by private industry feasible and desirable, if not imperative. As a result a thorough overhauling of the 1946 Act could no longer be postponed. ${ }^{8 B}$

The immediate impetus to legislative action was given by a message of the President of February 17, 1954 ${ }^{37}$ which urged revision of the existing law so as to furnish-among other objectives in the international field"improved procedures for the control and dissemination of atomic energy information" and "encouragement of broadened participation in the development of peacetime uses of atomic energy." In order to accomplish the

33 See AEC, Etghte Semitannuar Report 209 (1950); AEC, Tente Semiannuad Report 63, 147 (1951) ; AEC, ELEVENTH SEMTANNOAL REPORT 44, 192 (1952); subsequent reports.

34 Fletcher v. United States, 133 Ct. Cl. 896 (1956) ; Fletcher v. United States AEC, 192 F.2d 29 (D.C. Cir. 1951), cert. denied, 342 U.S. 914 (1952); Consolidated Engineering Corp. v. United States, 127 F. Supp. 558 (Ct. CI.), cert. denied, 349 U.S. 939 (1955).

${ }^{85}$ Term used in Message from the President, Transmitting Recommendations Relative to the Atomic Energy Act of 1946, H.R. Doc. No. 328, 83d Cong., 2d Sess. (1954); 1 LeGIStatrve History of THe Atomic Energy ACT OF 1954, 45 (AEC 1955).

36 The need for and the scope of new legislation were the subject of extensive public hearings held by the Joint Committee on Atomic Energy during June and July 1953, see Atomic Power Development and Private Enterprise, Hearings before the Joint Committee on Atomic Energy, 83d Cong., 1st Sess. (1953). Prior to these hearings the chairman of the Joint Counmittee and the chairman of its Reactor Development Subcommittee had inforned the Atomic Energy Commission that they would like to receive a statement on atomic power policy and a program of private industrial participation for consideration by the Joint Committee in executive session, id. at 62. Pursuant to these requests the Commission on May 26, 1956, transmitted a policy statement on atomic power development which had been submitted to and approved by the National Security Council, id. at 1,54 . This policy statement which was formulated in six points was again presented at the first day of the public hearings, id. at 6-7. Point $4 \mathrm{e}$ called for "more hberal patent rights than are presently granted to outside groups as may seem appropriate to the Commission and consistent with existing law," id. at 7 . The desirability of broadening the area of private patent rights was stressed by numerous witnesses at the hearings. Mr. Ooms, in particular, inade detailed proposals in this respect which exerted important influence on the final form of the Act of 1954, id. at $45 \%$.

37 Note 35 supra. 
latter goal the message recommended a carefully guarded, but drastic, relaxation of the government monopoly in the areas of production and utilization of atomic energy, coupled with a corresponding expansion of the area in which private patents could be obtained. However, in order to forestall the unfair acquisition of patent monopolies by contractors already in the field it was suggested that authority to require licensing of patented inventions essential to the peacetime applications of atomic energy should be continued for a limited period, estimated at five years. ${ }^{38}$

In pursuance of this request the Joint Committee on Atomic Energy drafted a proposed act to amend the Atomic Energy Act of 1946 which was introduced in both Houses in April, $1954 .^{39}$ The envisaged revision restored to the patent system a large portion of the sector which the 1946 legislation had withdrawn. Inventions useful solely in the utilization of "special material" ${ }^{10}$ or atomic energy in an atomic weapon remained unpatentable ${ }^{41}$ multiple application inventions were likewise not protectable by patents to the extent that they were used in such utilization. ${ }^{42}$ The proposed amendment also retained the privileged status of research in the atomic fields. ${ }^{40}$ The compulsory licensing provisions were eliminated and the powers of eminent domain and acquisition by purchase were restricted to inventions useful in the utilization of special material or atomic energy in an atomic weapon. ${ }^{44} \mathrm{~A}$ new section required the establishment of standard specifications, including reasonable royalty fees, for the grant of permits to use Commission-held patents. ${ }^{45}$ The Patent Compensation Board was to be abolished and with it the systein of merit awards for the inventors of nonpatentable or not wholly patentable inventions. ${ }^{48}$

In the hearings ${ }^{47}$ on the bill the proposed new patent regime was subjected to numerous criticisms as to draftsmanship and content. The testimony, especially that of Mr. Boskey, a former Deputy General Counsel of the AEC, and of spokesmen for the National Association of Manufacturers and the United States Chamber of Commerce, revealed the need for sev-

38 H.R. Doc. No. 328, 83d Cong., 2d Sess. 7 (1954) ; 1 Legislattve History of the Atomac ENERGY ACT OF 1954, 51 (AEC 1955).

39 H.R. 8862, 83d Cong., 2d Sess. 1954) ; S. 3323, 83d Cong., 2d Sess. (1954). For the identical texts of the Committee Print and the two bills see 1 LEgrstative History of THE Atomac ENERGY ACT of 1954, 53-104, 105-255 (AEC 1955).

40 "Special material" signified plutonium, uranium enriched in isotopes 233 or 235 and other materials determined to be special materials, H.R. 8862, 83d Cong., 2d Sess. §11s (1954).

41 H.R. 8862, 83d Cong., 2d Sess. (as originally introduced) § 151a (1954).

42 Id. $\S 151 \mathrm{~b}$.

$43 I d$. $\$ 152$.

$44 I d . \S 153$.

45 Id. \& 154 .

46 Id. $\S 155$.

47 Hearings before the Joint Committee on Atomic Energy on S. 3323 and H.R. 8862, 83d Cong., 2d Sess., 2 parts (1954). 
eral clarifications and the advisability of changes in policy. ${ }^{48} \mathrm{Mr}$. Boskey, in particular, advocated the re-introduction of the merit awards system for inventors in the field still excluded from patent protection or even under other deserving circumstances and, in conjunction therewith, the preservation of a separate adjudicatory body and of the right to counsel and judicial review. In addition he made a strong plea for the retention of a temporary system of compulsory licensing in consonance with the President's recommendations and urged a special savings clause to preserve rights accrued under the existing act. The spokesmen for the NAM objected with great vigor to the preservation of the limitation on patent rights with respect to research and developmental activities, empliasizing its discouraging effect on the manufacturer of laboratory equipment. ${ }^{49}$ As a result of this testimony the Joint Committee on May 21, 1954, produced a revamped draft ${ }^{50}$ which was subjected to further hearings.

The new form of the bill retained non-patentability with respect to the utilization of special nuclear material or atomic energy in an atomic weapon and the duty to commumicate such inventions to the Commission or Patent Office. ${ }^{51}$ The special patent status of research and developmental activities, as well as the special powers of condemnation and requisition, were eliminated. Instead, the revision accorded the Commission general powers to acquire patents by purchase ${ }^{52}$ and, moreover, predicated the acquisition of patents for inventions useful in the production or utilization of special nuclear material either upon a sworn statement by the applicant "as to whether the invention described in the application was not made or conceived during the course of, in connection with, or under the terms of any contract, subcontract, arrangement or other relationship with the Commission, other than as licensee under this Act, ..." or upon express consent by the Commission. ${ }^{53}$ The new wording of the bill made it clear that the practice of granting royalty-free licenses on Commission-held patents could be continued ${ }^{54}$ and introduced a broad merit awards system for inventors making discoveries useful in the production or utilization of special nuclear inaterials or atomic energy or used in the conduct of research or development fields covered by the act. ${ }^{55}$ Lastly, it incorporated an express savings clause..$^{56}$

48 Id. at $123-54,359-74,454-75$.

$49 \mathrm{Id}$. at 459,463 .

50 Committee Print of H.R. 8862, S. 3323, dated May 21, 1954, reproduced in 1 LEGISLATTVE History OF TEE ATOMIC ENERGY ACT OF 1954, 257 (AEC 1955).

51 H.R. 8862 (in form of Committee proposal, dated May 21, 1954) § 151.

$52 Y d$. $\$ 161 \mathrm{~g}$.

$53 \mathrm{Id}$. 152 .

54 Id. § 153 .

ถ5 Id. § 154 .

$56 I d . \S 155$. 
The representatives of the AEC, when presenting their views on the new edition of the bill, ${ }^{57}$ urged expansion of the statutory duty to report inventions to the Commission so as to embrace the whole area of production or utilization of special nuclear material and to restore the obligation of the Patent Office to notify the Commission of all applications in these fields. ${ }^{58}$ They came out in favor of a limited and temporary compulsory licensing program like that recommended by the President's message ${ }^{60}$ and, while endorsing the broadening of the award system, recommended retention of the Patent Compensation Board ${ }^{60}$ They advised against the deletion of the privileged status of research and developmental activities ${ }^{01}$ and suggested express legislative recognition of the power to insert suitable patent clauses in the contractual arrangements with the Commission. ${ }^{62}$

As a result of this position and despite violent disagreement within the Joint Committee a further version of the bill and particularly of its patent provisions was drafted and, after introduction as S. 3690 and H.R. 9757, recommended for passage in the report of the Committee. ${ }^{63}$ The new patent sections preserved the non-patentability of utilizations of special nuclear material or atomic energy in atomic weapons, but established a broad duty of notification with respect to any inventions useful in the production or any utilization of special nuclear material or atomic energy. ${ }^{64}$ They incorporated an elaborate and carefully hedged system of compulsory compensable hicensing of patents covering inventions having primary importance in the production or utilization of special nuclear material or atomic energy to be in force for a five-year period..$^{65}$ It was newly specified that anticipa-

67 Hearings before the Joint Committee on Atomic Energy on S. 3323 and H.R. 8862, 83d Cong., 2d Sess., Part II, 561 et seq. (1954).

68 Id. at 597, 598. The Commission felt that it could perform its steering functions in the course of development only if constantly apprised of private achievement.

59 Id. at 598, 649-70. It may be worth noting that Commissioner Campbell in this connection criticized the principle of proposed $\$ 152$ which became the forerunner of the present provision having the same numbering. $I d$. at 598 .

60 Id. at 599,679 .

61 Id. at 599. Commissioner Campbell observed that research on a patented invention would not constitute infringement within the meaning of the patent law, but that use of a patented invention in research would not be privileged. As to the first proposition see the doubts expressed in Bee, Experimental Use as an Act of Patent Infringement, $39 \mathrm{~J}$. PAт. OxF. Soc'y 357 (1957).

62 Id. at 667.

63 Amending the Atomic Energy Act of 1946, as amended, and for other proposes, S. RaP. No. 1699, 83d Cong., 2d Sess. (1954), H.R. Rer. No. 2181, 83d Cong., 2d Sess. (1954).

64 H.R. 9757 and S. 3690, 83d Cong., 2d Sess. § 151a-d (1954).

65 Id. $\$ \$ 152,153$. The system employed followed proposals made by Mr. Ooms in Atomic Power Development and Private Enterprise, Hearings Before the Joint Committee on Atomic Energy, 83d Cong., 2d Sess. 457 (1954), and eliminated the automatic hicensing following from a declaration that a patent be affected with the public interest, requiring instead that each private applicant for license must demonstrate that such action is necessary to effectuate the policies and purposes of the act. 
tion because of prior knowledge or use should not be denied because such knowledge or use was under secrecy within the atomic energy program. ${ }^{60}$ Recognition was accorded to the power of the Commission to grant licenses on Commission-held patents pursuant to standard specifications ${ }^{67}$ and to require that patents for inventions made or conceived during the course of federally financed research or operation be assigned to the United States. ${ }^{68}$ Provision was made for the grant of reasonable royalty fees, just conipensation or awards for inventors barred from compensation or royalty or otherwise neritorious after consideration by a Patent Compensation Advisory Board. ${ }^{69}$ Finally, one of the sections contained a specific savings clause. ${ }^{70}$ Some members of the Joint Committee, including its chairman, added detailed dissenting statements in the report on the bill ${ }^{71}$ and thus set the stage for a lively and tenacious Congressional battle.

In the House of Representatives Mr. Cole, then chairman of the Joint Committee, registered an impassioned protest against the constitutionality and Americanism of conpulsory licensing ${ }^{72}$ and advocated an amendment giving the Commission the status of the originator of inventions useful in the production or utilization of special nuclear material or atomic energy if made or conceived under any contract, subcontract, arrangement or other relationship with the Commission. This change and the necessary conforming amendinents were adopted. ${ }^{73}$ Conversely, in the other chamber, Senator Kerr succeeded with a proposal extending the period of compulsory licensing from 5 to 10 years, restricting it at the same time to the non-exclusive type, ${ }^{74}$ and Senators Langer and Johnston induced their colleagues to add a new provision, decreeing forfeiture to the federal government of a patent for inventions useful in the utilization or production of special nuclear material or atomic energy upon its owner having been found to have used the same intentionally for a violation of the antitrust laws. ${ }^{75}$ Since the Senate refused to pass the House of Representatives approved version of

\footnotetext{
${ }^{68}$ H.R. 9757 and S. 3690, 83d Cong., 2d Sess. \$154 (1954).

67 Id. \$155.

BS Id, \$157.

69 Id. \& 156. The Board was restyled as the Patent Compensation Board by subsequent Committee action and this amendment was accepted by both Houses, 100 Cong. Rec. 10685, 10686, 11687 (1954).

70 H.R. 9757 and S. 3690, 83d Cong., 2d Sess. $\$ 158$ (1954).

71 S. REP. No. 1699, 83d Cong., 2d Sess. 95-99 (Cole and Van Zandt), 105-138, especially 126-130 (Holifield and Price) (1954) ; H.R. ReP. No. 2181, 83d Cong., 2d Sess. 95-99, 105-138, especially 126-130 (1954).

72100 Cong. Rec. 11658, 11721 (1954); 100 Cong. Rec. A 5356 (1954).

78 Id. 11729.

74. Id. 12002, 12003.

75 Id. $11987,12227,12230,12239,12240$.

70 Id. 12242.
} 
the bill ${ }^{78}$ and the House disagreed with the Senate amendments ${ }^{77}$ a conference was called. The conference committee decided to find a new approach to reconcile the divergent House and Senate patent policies and at the same time avoid outright compulsory licensing. The committee drafted a bill which retained the House provisions vesting inventor status in the AEC with respect to inventions useful in the production or utilization of special nuclear material or atomic energy if made or conceived under contract or other arrangement with the Commission and at the same time provided that applicants for commercial licenses should in the next five years be entitled to preferred consideration if they agreed to make their atomic energy patents available to all other licensees demonstrating need therefor and willing to pay reasonable royalty fees as determined by the Patent Compensation Board. In addition, certain changes were made in the language of the Langer-Johnston clause relating to antitrust violations. ${ }^{78}$

The Senate, however, rejected the conference report, at least in part, because of the absence of compulsory licensing provisions, and requested a further conference ${ }^{79}$ which was agreed to by the House. ${ }^{80}$ In the second conference, therefore, the committee members, in part reluctantly, agreed upon combining a five-year regime of compulsory licensing of the type insisted upon by the Senate with a system giving the AEC inventor status with respect to inventions in the atomic energy field conceived or made under arrangements with the Commission. ${ }^{81}$ In this form the report was approved by both Houses ${ }^{82}$ and the bill thus redrafted finally became the Atomic Energy Act of $1954 .{ }^{83}$

\section{B. The Present Regime:}

\section{Wolves in Sheep's Clothing, Sheep in Wolves' Clothing or Just Sheep?}

It is no surprise that the present system shows the marks of its tempestuous conception and its birth by compromise. Its complex contours are anything but clear-cut and its blurred lines defy all attempts to bring them into focus. As a result the controlling provisions have prompted a number

77 Id. 12438.

78 Atomic Energy Act of 1954, Conference Report, H.R. REP. No. 2639, 83d Cong., 2 d Sess. 27-30, 36, 48-49 (1954).

79100 CoNG. Rec. 14364 (1954).

80 Id. 14628.

81 Atomic Energy Act of 1954, Conference Report, H.R. ReP. No. 2666, 83d Cong., 2d Sess., 27-32, 50-51 (1954).

82100 Cong. Rec. 14606 (Senate), 14873 (House) (1954).

83 Pub. L. No. 703, 83d Cong., 2d Sess. (1954). 
of analyses and studies ${ }^{84}$ and formed the object of numerous Congressional hearings and inquiries ${ }^{85}$ as well as of amendatory bills. ${ }^{86}$

Basically the new sections may be classified as dealing with four interrelated areas: (1) Establishment of a threefold regime of Non-Patentability, Government Held Patents and Private Patents. (2) Temporary and potential subjection of private patents to compulsory licensing. (3) Provision for a subsidiary and supplementary system of compensatory or appreciatory awards. (4) Regulation of patent consequences of secret development and use and of antitrust violations.

We now turn to a consideration of these subjects.

\section{Non-Patentability, Government Patents and Private Patents}

Like Gaul the area of nuclear technology is divided into three parts: a zone of non-patentability, a zone of government patents, and a zone of private patent rights. The broad underlying reason for this arrangement, of course, is the fact that certain pliases of nuclear technology, by reason both of the urgency of its development and the necessity for secrecy, are a closely guarded government monopoly and that other aspects still need active promotion and supervision by the government.

(a) Non-patentability of atomic weapon inventions. This sector covers the utilization of special nuclear material or atomic energy in an atomic

84 See especially Adams, Atomic Energy: The Congressional Abandonment of Competition, 55 CoLUMr. L. REv. 158, especially at 160-67 (1955); Beckett \& Merriman, Will the Patent Provisions of the Atomic Energy Act of 1954 Promote Progress or Stifle Invention?, 23 Geo. Wash. L. Rev. 195 (1954), reprinted, 37 J. Pat. OFF. Soc'צ 38 (1955) ; Boskey, Patents Under the New Atonic Energy Act, 36 J. Par. OFF. Soc'Y 867 (1954); Boskey, Some Patent Aspects of Atomic Power Development, 21 Law \& Contrarp. Prob. 113 (1956) ; Boskey, Progress and Patents in Atomic Energy: The Military and the Civitian Uses, 34 TeXAs L. REv. 867 (1956); Brownell, Atonic Energy and Free Enterprise, 1957 ANTrTRust LAW Syarposrom 11 (CCH 1957) ; Cole, Patenting Nuclear Developments, 13 Nucceonrcs, No. 4, 31-35 (1955) ; Dunlavey, Government Regulation of Atomic Energy, 105 U. PA. L. REv. 295, especially at 334-42 (1957); Mackey, Corporate Practice in the Atomic Field, Amereacan Patent L. Assoc. Bulr. 348 (1957); Ooms, Revisions of the Patent Provisions-Good or Bad, Natronal Industruad ConFerence Board, Minutes of 3D ANNuat Conference on Atomic EnERgy IN Industry 279 (1954); Ooms, Sone Suggestions Relating to the Patent Provisions in Atomic Energy Legislation to Protect the Public Interest, 38 J. Pat. OFF. Soc'Y 38 (1956); Patent Problems in Atonic Energy, Worzshops on Legar Problems of Atomac Energy, U. of Michugan LaW Schoor 85 (1956); Wiles, The Atomic Energy Act of 1954, Axr. Pat. L. Ass'n Bulx. 343 (1957).

85 See especially annual hearings on Development, Growth and State of the Atomic Energy Industry, Hearings Before the Joint Committee on Atomic Energy, 84th Cong., 1st Sess., 3 pts. (1955); Hearings Before the Joint Committee on Atomic Energy, 84th Cong., 2d Sess., 2 pts. (1956); Hearings Before the Joint Committee on Atomic Energy, 85th Cong., 1st Sess., 2 pts. and index (1957); see further Peaceful Uses of Atomic Energy, Report of the Panel on the Impact of the Peaceful Uses of Atomic Energy to the Joint Committee on Atomic Energy, 84th Cong., 2d Sess. (2 vols. 1956), especially vol. 1, at 145; vol. 2, at 657-73 and 712-16.

86 See especially H.R. 5694, 85th Cong., Ist Sess. (1957) (so-called Cole Bill). 
weapon. An invention which is solely useful in such manner is totally nonpatentable subject matter ${ }^{87}$ an invention which also has other utilizations may enjoy patent protection, but the scope of this protection does not include the military use. ${ }^{88}$ The rationale for this regulation is, of course, the fact that the production of atomic weapons is an exclusive government domain ${ }^{89}$ and that, as under the 1946 Act, $^{90}$ it was thought futile to accord patent rights for inventions with respect to practices which are permitted only to the government. ${ }^{91}$ Accordingly, as far as inventions possess also non-military utilizations they remain patentable; but it must be noted that such applications may nevertheless fall under the general secrecy provisions of the Patent Act ${ }^{92}$ and therefore possess only deferred patentability. ${ }^{93}$ Of course, whether a particular invention is "solely" useful for utilization in an atomic weapon may sometimes be difficult to decide and, in view of the needed secrecy, perhaps not capable of timely judicial determination. ${ }^{\text {a4 }}$

In order to keep the AEC informed of technological advances which may have military utilizations and require secrecy as well as to facilitate its role of acting as the nerve center in this branch of technology, the statute imposes upon the originator of an invention useful in the production or any utilization, whether in an atomic weapon or not, of special nuclear material or atomic energy the duty of making a timely report thereof to the AEC unless the invention is described in a patent application. If the latter is the case the Commissioner of Patents must notify the AEC. ${ }^{\text {o5 }}$ According to available statistics, in 1956 the Patent Office reported 450 applications under this section, as compared with 135 in the previous year and 50 in

8768 STAT. 943 (1954), 42 U.S.C. $\$ 2181$ (a) (Supp. IV 1957).

88 Ibid., 42 U.S.C. $\$ 2181$ (b) (Supp. TV 1957).

89 Id. at 936 (1954), 42 U.S.C. $\$ \S 2121,2122$ (Supp. IV 1957).

80 See supro text to notes 8,11 and 12. See also Boskey, Inventions and the Atom, 50 Colom. L. Rev. 433, 435 (1950); Ooms, The Patent Provisions of the Atomic Energy Act, $15 \mathrm{U}$. CEI. L. Rev. 822, 826 (1948).

91 See also, Boskey, Progress and Patents in Atomic Energy; The Military and the Civilian Uses, 34 Texas L. Rev. 867, 871 (1956) ; Boskey, Some Patent Aspects of Alomic Power Development, 21 LAW \& CONTEMr. Prob. 113, 117 (1956); Ooms, Some Suggestions Relating to Patent Provisions in Alomic Energy Legislation to Protect the Public Interest, 38 J. Par. Orp. Soc'Y 38, 55 (1956).

0266 STAT. 805,35 U.S.C. $\$ 181$ (1952).

${ }^{03}$ See also the statement by the AEC in Development, Growth and State of the Atomic Energy Industry, Hearings Before the Joint Committee on Atomic Energy, 85th Cong., 1st Sess., pt. 1, 77, 109, 304 (1957).

94 For similar problems formerly arising under $\$ 11$ (a)(1) of the Act of 1946 see Ooms, Problents of Patent Policy for Government and Industry in Atomic Energy, LecruRES ox Atomitc Energy Industrial and Legal Problems 155, 166 (U. of Mich. 1952).

9568 STAT. 943 (1954), 42 U.S.C. $\$ 2181$ (b) (Supp. IV 1957). The compliance with this provision is assured by Rules of Practice in Patent Cases, 37 C.F.R. \$ 1.14(c) (Supp. 1957); cf. Wiles, The Atomic Energy Act of 1954, Amarican Patent L. Assoc. Buld. 343, 345 (1957). 
$1954 .{ }^{96}$ Of these applications 19 were subject to secrecy orders in effect on March 4, 1957..$^{77}$ Both the breadth and the vagueness as to scope and sanctions of this imposition on the inventor of a special duty to report have been severely criticized. ${ }^{88}$ It would seem that, independently of contractual relations, a duty of the inventor to report directly to the AEC might well be confined to, at the most, inventions $u$ seful in the utilization in weapons. ${ }^{.9}$

(b) Government patents. Unquestionably the rules governing the acquisition of patents by the government have proven to be the bettes noirs of the flock. Apart from the innocuous authorization of obtaining patents through purchase, ${ }^{100}$ two overlapping and seemingly inconsistent sections control the field; these are sections 152 and 159.

Section 159 specifies that "nothing in the Act shall affect the right of the Commission to require that patents granted on inventions made or conceived during the course of federally financed research or operation be assigued to the United States." As mentioned before, ${ }^{101}$ this section was inserted into the Act for the purpose of rendering it clear that the dropping of the condemnation clause contained in the original Act did not signify that Congress rejected the practice of including the $\mathrm{A}, \mathrm{B}$, or $\mathrm{C}$ type of patent provisions in AEC contracts as developed under the 1946 regime. Under the first and most sweeping form of these clauses the contractor concedes to the Commission the sole power to determine (1) whether or not and where a patent application shall be filed for any invention made or conceived by the contractor or its employees under the contract and (2) what disposition shall take place of the title to and rights under any

80 See statement by AEC, Development, Growth and State of the Atomic Energy Industry, Hearings Before the Joint Committee on Atomic Energy, 85th Cong., 1st Sess., pt. 1, 109, 305 (1957).

07 Id. at 305 .

08 See especially Boskey, Some Patent Aspects of Atomic Power Development, 21 LAw \& Contenr. Prob. 113, 123-26 (1956); Patent Problems in Atomic Energy, WorksHops on Legat Problents of Atonrc Energy 85, 89 (1956). But contrast Ooms, Some Suggestions Relating to Patent Provisions in Atonic Energy Legislation to Protect the Public Interest, 38 J. PAT. OFF. SOc'צ 38, 47, 56 (1956) (calling the reporting provisions "satisfactory"). One of the reasons advanced for the criticism rests on the computation of the period set for the reporting which is measured from the time either of the "completion" of the invention or when the inventor first realizes or has reason to believe that his invention is useful in the production or utilization of special nuclear material or atomic energy. Apparently "completion" signifies actual reduction to practice. Another disturbing doubt concerns the effects of non-compliance with the reporting duty on the validity of the patent (not otherwise proscribed or vested in the government), especially in an infringement suit.

00 F.R. 5694, 85th Cong., 1st Sess. (1957), supra note 86, does not contemplate any changes in $\$ 151(\mathrm{c})$ of the Act.

10068 STAT. 949 (1954), 42 U.S.C. § 2201(g) (Supp. IV 1957).

101 Text to note 62 supra. 
application or patent that may result. ${ }^{102}$ Under the other two versions of the clauses the contractor makes a similar arrangement but retains either "at least a non-exclusive, irrevocable, royalty-free license" or "at least a sole (except against the Government or its account), irrevocable, royaltyfree license with the sole riglit to grant sublicenses" excluding, however, use in the production or utilization of special nuclear material or atomic energy. ${ }^{103}$

Section 152, contrariwise, goes much further and ordains in its first sentence that "any invention or discovery, useful in the production or utilization of special nuclear material or atomic energy, made or conceived under any contract, subcontract arrangement, or other relationship with the Commission, regardless of whetler the contract or arrangement in-

102 The first two paragraphs of the type A clause read currently as follows: "(1) Whenever any invention or discovery is made or conceived by the Contractor or its employees in the course of, in connection with, or under the terms of this contract, the Contractor shall furnish the Commission with complete information thereon; and the Commission shall have the sole power to determine whether or not and where a patent application shall be filed, and to determine the disposition of the title to and rights under any application or patent that may result. The judgment of the Commission on these matters shall be accepted as final, and the Contractor, for itself and for its employees, agrees that the inventor or inventors will execute all documents and do all things necessary and proper to carry out the judgment of the Commission. (2) No claim for pecuniary award or compensation under the provisions of the Atomic Energy Acts of 1946 and 1956 shall be asserted by the Contractor or its employees with respect to any invention or discovery made or conceived in the course of, in connection with, or under the terms of this contract." The remaining two paragraphs obligate the contractor to insert corresponding provisions in his employment or subcontracting agreements. See AEC Manvax, c. 9113, §013 (as revised June 20, 1955), reprinted, CCH Aroms. EN. Law REP. I 3405. This type of clause is employed "when the work to be performed or the material or equipment to be furnished by the contractor is of such character that any inventions or discoveries that may be made probably will relate directly to or concern sone phase of the research or development work which AEC conducts or sponsors." Ibid. For the development of the wording of the clause see also the communication of the AEC to the McKinney Panel, Peaceful Uses of Atomic Energy, Report of the Panel on the Impact of the Peaceful Uses of Atomic Energy to the Joint Committee on Atomic Energy, 84th Cong., 2d Sess., vol. 2, 672 (1956).

103 AEC MaNUAL, c. 9113, \$§ 014, 015 (1955), reprinted in CCH Atom. EN. Law Rep. III 3406 and 3407. These types of clauses are used when the work to be performed or the material or equipment to be furnished by the contractor is of such character that any inventions or discoveries that may be made probably (a) will relate only incidentally (and not directly) to some phase of the basic research or developnent work which AEC conducts or sponsors, but (b) will relate to a field of work in which the contractor has an established industrial and patent position, type $\mathbf{C}$ being employed if such invention or discovery, in addition, results from routine development or production work by the contractor. Finally the Commission has developed a special " $\mathrm{C}+$ type" of clause for use in power study, access, and some commercial agreements. This clause gives the contractor an exclusive (except against the government), irrevocable, royalty-free hicense for uses other than in the production or utilization of special nuclear unaterials or atomic energy and a non-exclusive, irrevocable, royalty-free license for the latter uses; see statement by the General Counsel of the Commission in Development, Growth and State of the Atomic Energy Industry, Hearings Before the Joint Committee on Atomic Energy, 84th Cong., 1st Sess. 193 (1955). 
volved the expenditure of funds by the Commission, shall be deemed to have been made or conceived by the Commission, except that the Commission may waive its claim to any such invention or discovery, if made or conceived by any person at or in connection with any laboratory under the jurisdiction of the Commission ... or under such other circumstances as the Commission may deem appropriate." The provision thus made is implemented by a statutory duty of disclosure and elaborate rules regulating the determination of controversies about the circumstances of particular inventions. ${ }^{104}$

There is no doubt that the substantive part of the section grossly overshoots the mark in many directions, ${ }^{105}$ though luckily tempered by the somewhat unguided permission of discretionary administrative waivers. ${ }^{100}$ Certainly its sweeping disregard of the time-honored inventor principle is of questionable wisdom and leads to all kinds of unnecessary complications and inconsistencies with other patent law rules and practices. It is one of the real ironies of fate that this constitutionally dubious ${ }^{107}$ and, at any rate, uncalled-for departure from one of the basic tenets of American patent law was railroaded into the Act by its unwary author ${ }^{108}$ in order to combat

10468 STAT. 944 (1954), 42 U.S.C. $\$ 2182$, para. 1, second and third sentences, para. 2 and para. 3 (Supp. IV 1957). The duty must be performed by filing the requisite report either together with any patent application for an invention useful in the production or utilization of special nuclear material or atomic energy, or within thirty days after request by the Commissioner of Patents. The Commissioner must thereafter forward the information to the AEC. Again the question arises whether omission to file such report vitiates the patent if issued despite such failure even where no contract is actually mvolved, especially in view of the language: "no patent . . . shall be issued . . . " For a discusion of the scope of the duty under $\S 152$ of the act and the Patent Office procedure pertaining thereto see Wiles, The Atomic Energy Act of 1954, American Patent L. Assoc. Bulc. 343, 346 (1957). According to a statement by the AEC in March 195\%, the Patent Office during 1956 made about 30 referrals under \$ 152, see Development, Growth and State of the Atomic Energy Industry, Hearings Before the Joint Committee on Atomic Energy, 85th Cong., 1st Sess., pt. 1, 305 (1957).

105 See especially the comments by Boskey, Some Patent Aspects of Atomic Power Devel opment, 21 Law \& Contenrp. Prob. 113, 126, 131 (1956); Cole, Patenting Nuclear Developments, 13 NucLEonics No. 4 at 31,34 (1955). As the latter author poimts out in these comments, all that was intended was to provide for "a procedural device for giving the Commission ready title to those patents to which it is entitled." (Emphasis added.)

100 "Simce January 1956, the Colnmission issued waivers of rights under Section 152 of the Act of 1954 as respects three general categories: (1) Inventions and discoveries made or conceived as a result of access to restricted data (the waiver was incorporated in Part 25 of Title 10, C.F.R., Section 25.3 ...) ; (2) Licenses issued by the Commission (the Opinion of the General Counsel was published as an interpretation in Title 10, C.F.R., Part 8 ...) ; and (3) Inventions and discoveries made as a result of use of materials sold, distributed or leased, or otherwise made available, including radioactive and stable isotopes and services sold or otherwise made available including irradiation services (Fimal rules were published . . as Part 83 of Title 10, C.F.R. ...)" AEC, Twenty-FIRST SeAtIAnNuad Report 105 (1957).

107 See the observations by Cole in Patenting Nuclear Developments, 13 Nucteonics, Nos. 4, 31, 34 (1955).

108 (Then) Representative Cole himself admitted in 1955: "Ironically under the pressure of zealously trying to protect the normal American patent system, too much was written into this section." Id. at 34 . 
the purported un-Americanism of compulsory licensing-incidentally also without awareness that a recommendation to the same effect by Secretary Wallace at the framing of the first $\mathrm{Act}^{109}$ had not found acceptance by the drafters.

Although seemingly couched in the terms of a presumption the true import of the section is as a rule of $l a w^{110}$ which covers all inventions $u s e f u l$ in the production or utilization of special nuclear material or atomic energy - a very broad category-and therefore actually would leave little, if any, room for the operation of the contract patent clauses; this is especially true if one should conclude that the waivers authorized by the Act are indicated mainly by reason of the tenuousness of contact with the government in the making of the invention. ${ }^{111}$ Although up to date no particular difficulties have arisen in the administration of section $152,^{112}$ there seems to be no escape from the fact that troubles and embarrassment are bound to arise, once government inventorship by statutory fiat is taken literally. Its pernicious effects are especially apparent when it comes to the taking out of foreign patents for American inventions and in this respect serious complaints and justified anxieties have been voiced. ${ }^{118}$ To be sure, the AEC has alleviated the situation by permitting Commission contract inventions to be made the subject of foreign patent applications if the contractor so

109 See text to note 8 supra.

110 That facet is apparently overlooked by Ooms, Some Suggestions Relating to Patent Provisions in Atomic Energy Legislation to Protect the Public Interest, 38 J. PAT. OFF. Soc'z 38,56 (1956).

111 See the comments to that effect by Representative Cole in Patenting Nuclear Developnients, 13 NUcleonIcs No. 4, at 34 (1955). In 1955 (then) General Counsel Mitchell complained bitterly about the lack of statutory standards for determining when it is "appropriate" to waive the property rights which the act vests in the government, Development, Growth and State of the Atomic Energy Industry, Hearings Before the Joint Committee on Atomic Energy, 84th Cong., 1st Sess., pt. 1, at 194 (1955). It should, however, also be noted, that Mr. Mitehell testified on the same occasion: "To the extent that the Commission would be entitled, under section 152 of the Act, to any invention or discovery the rights to which are retained by the contractor under the various types of clauses inentioned above, the Commission has determined that it is appropriate under the statute to waive its rights to any such invention or discovery." Id. at 193 (Emphasis added).

112 As mentioned, supra note 104, during 1956 about 30 patent application referrals were made under section 152, and as to these the Commission did not file any directive under section 152, para. 2. According to information by the AEC there were several instances where tho Commission asserted rights in such cases, but after investigation and review the assignees concurred in the Commission's indicated rights so that there was no occasion to file any directive with the Commissioner of Patents. At present there are several cases under review. Development, Growth and State of the Atomic Energy Industry, Hearings Before the Joint Comnittee on Atonic Energy, 85th Cong., 1st Sess., pt. 1, 305 (1957).

113 See, e.g., the testimony by Mr. Starr before the Jomt Committee on Atomic Energy, Development, Growth and State of the Atomic Energy Industry, Hearings Before the Joint Conimittee on Atomic Energy, 85th Cong., 1st Sess., 203, 211, 302 (1957). 
desires and the invention does not involve classified matter. ${ }^{114}$ But while this practice might be consonant with section 159 of the act, its harmony with the automatic vesting provision of section 152 is not so free from doubt and may easily discourage foreign filing by the contractor. Moreover, the reaction of the other patent laws to inventions "deemed to be made" by a foreign government agency remains to be seen, after the existence of the pertinent clause becomes known abroad. Certainly the first sentence of section 152 fulfills no valid function and ought to be removed from the statute with dispatch. One of the objectives of H.R. 600, introduced early in January 1957 by Representative Cole, ${ }^{115}$ accomplishes this result and to that extent deserves and has found general approval. ${ }^{116}$

It may perhaps be legitimate to ask what purposes are served by the governunent's securing patent protection for inventions, if at the same time it embarks upon a program of making the practice thereof available to all interested parties without charge, ${ }^{117}$ rather than merely insisting that the inventions in question be dedicated to the public. The answer lies in certain managerial and strategic advantages gained by patenting even under such circumstances. As a patentee the government is in a stronger position to protect the invention against usurpation by a subsequent claimant, to give its licensees a greater assurance of freedom from infringement actions, and to retain information about and, if necessary, control over the extent to which the public is served by the process, product or device in question. ${ }^{118}$

114 See the statements of the AEC in that respect in the AEC, TwENTY-FIRST SEMrIANNUAI REPORT 105 (1957) and in Hearings Before the Joint Committee on Atomic Energy, 85th Cong., 1st Sess. 301 (1957) ; but note that the General Counsel intimated at the hearings that the patent issuing upon such foreign apphication covering a Commission contract invention might not inure to the sole benefit of the contractor but would be held in trust for all U.S. concerns(!). See also, AEC MANuaI, c. 9113, \$0113 (1955).

115 H.R. 600, 85th Cong., 1st Sess. (1957). The same amendment was proposed in the inore comprehensive bill H.R. 5694, 85th Cong., 1st Sess. (1957), also introduced by Mr. Cole.

116 See, e.g., the testimony in Hearings Before the Joint Committee on Atomic Energy, 85th Cong., 1st Sess. 240 (Chairman of the Atomic Energy Committee of the New York Patent Law Association), 550 (Vice-chairman of Committee on Patents of N.A.M.) (1957).

117 The AEC embarked on its program of granting non-exclusive royalty-free licenses to Commission-held patents at the end of 1949 , see text to note 33 supra. In January 1957 the Coinmission reported that some 1100 patents had been unade available in that fashion and that about 580 such licenses had been granted, AEC, TwENTY-FIRST SEMTANNuAL REPoRT 104 (1957). The first list of patents offered for licensing was published in the AEC, TENTE SentrannuaI REPORT 147 (1951); supplementary lists have been published from time to time in various subsequent semiannual reports.

118 The technical advantages flowing from patenting and general licensing as compared with dedication are discussed in detail in 1 Investigation of Governarent Patent Practices and Poitcies, Report and Recommendations of the Attorney Generat to the Presment 126-30 (1947) ; Foraran, Patents, Their OWNersemp and AdMmistration BY THE UntTed States Governarent 41 (1957); Saragovitz, Procurement of Patents by Government Agencies, 37 J. PAT. OFF. Soc'y 677 (1955); see also the testimony by Captain Lavender, Hearings Before Senate Special Conmittee on Atomic Energy on S.1717, 79th Cong., 2d Sess. 345 (1946), discussed by Newman \& Miller, Patents and Atomic Energy, 12 Law \& ConTEMP. ProB. 746, 747 (1947). 
As a result it makes good sense to have, in addition to the areas of nonpatentability and of private patents, an intermediate zone of government patent rights, especially where the particular inventions are made possible directly or indirectly, in whole or to a substantial extent through public expenditures. Unfortunately the details defy a hard and fast definition. Section 159, while based upon a sound policy, appears to be both too narrow and too rigid in its formulation. The AEC ought to be vested with untrammeled power to make such arrangements concerning rights to and under patents as are fair and equitable in the light of actual contributions made by the government and by the contractor. ${ }^{110}$

\section{Compulsory Licensing}

Comparatively little needs to be said at this date about the "prolix," "unduly cumbersome" and "extremely limited" provisions ${ }^{120}$ pertaining to compulsory licensing of private patents covering inventions of "primary" importance in the production or utilization of special nuclear material or atomic energy. ${ }^{121}$ As has been discussed before, the sections in question were inserted into the act in order to make sure that the dissipation of the government monopoly in the atomic power field would not enable a few big corporations that had acquired a vast body of experience as recipients of government funds to use their position in the race to build up an impenetrable patent monopoly in the field. Actually the act envisages two alternative avenues for such compulsory licenses, one being opened by the Commission on its own initiative through a formal declaration that a patent for an invention of the critical type is affected with the public interest, ${ }^{122}$ the other being pursuable without such preliminary Commission action by any

119 For a good general discussion of the problem of patent rights of government contractors at the close of World War II, see Kreeger, The Control of Patent Rights Resulting from Federal Research, 12 LAw \& ConTEMRP. PROB. 714, 734-45 (1947); Investioation OF GOVERNMENT Patent Practices and Poltcies, Report and Recomanendations of the Attorney Generat TO THE Presment (3 vols. 1947). The current patent clauses in Defense Department and Army Department experimental, developmental or research contracts not relating to atomic energy are governed by 32 C.F.R. $\$ \$ 9.107-1,598.107-1$, which leave title to the invention with the contractor, see the discussion by Hodges, Patent Policies and Procedures of the Department of the Army, 39 J. Par. OfF. Soc'y 192, 204 (1957). The rules applicable to patent clauses in such contracts relating to atomic energy are 32 C.F.R. $\$ 9.107-1$, as amended, 22 FED. REG. 6325 (1957), and 32 C.F.R. $\$ 598.107-2$. For the patent provisions in research grants and other research arrangements by the Department of Health, Education and Welfare, see 45 C.F.R. pt. 8 (Supp. 1957).

120 Characterization given to the section by Representatives Ilolifield and Price in S. REP. No. 1699 on S. 3690, 83d Cong., 2d Sess. 127 (1954) and H.R. REp. No. 2181 on H.R. 9757, 83d Cong., 2d Sess. 127 (1954).

12168 StaT. 945 (1954), 42 U.S.C. $\$ 2183$ (Supp. IV 1957); 68 StaT. 946 (1954), 42 U.S.C. $\S 2184$ (Supp. IV 1957).

12268 STaT. 945 (1954), 42 U.S.C. $\$ 2183$ (a) and (h) (Supp. IV 1957). 
applicant for or holder of a license, permit, lease or authorization under the act. ${ }^{123}$

It seems to be almost inexplicable that this system precipitated such a truly quixotic attack in Congress and prompted such an effusion of words and ink. Its prospects for ever being invoked are dim indeed. In the first place, the whole matter is merely transitional in that it covers only patents applied for prior to September 1, 1959, although it does affect such patents for their whole seventeen years' life after their eventual issuance. ${ }^{124}$ In the second place, the officials of the Commission are on record that, as under the 1946 Act, they look at the compulsory licensing provisions merely as a "reserve power" not to be actuated "except under compelling circumstances."125 As a matter of fact the Commission has no practical reason to resort to compulsory licensing for the purpose of serving its own exigencies $^{126}$ as it and its contractors are sufficiently protected under a general provision which in effect restricts a patent owner to a clain for reasonable royalty fee against the government whenever an invention is used or manufactured by the United States, or for it by a contractor, subcontractor or other authorized person. ${ }^{12 \tau}$ There is likewise little ground to surmise that private industry will invoke these procedures to an appreciable extent and with success. The experience under foreign laws seems to dennonstrate the contrary. For example, im Germany, a most important industrial nation which has had compulsory licensing in the public interest as a feature of its general patent system since $1911,{ }^{128}$ only twenty such applications were granted in the period between 1920 and 1935, and none were affirmatively determined since the restoration of the patent system in $1950 .{ }^{129}$

12368 STAT. 945 (1954), 42 U.S.C. § 2183 (c)-(e) (Supp. IV 1957).

12468 Star. 945 (1954), 42 U.S.C. $\$ 2183$ (h) (Supp. IV 1957).

125 Development, Growth and State of the Atomic Energy Industry, Hearings Before the Joint Comnittee on Atomic Energy, 84th Cong., 1st Sess. 194 (1955).

126 A declaration that a patent of the specified type is affected with the public interest vests the Commission with an automatic license to practice the invention, 68 STAT. 945 (1954), 42 U.S.C. § 2183 (b) (1) (Supp. IV 1957).

12762 STAT. 941 (1948), 28 U.S.C. $\$ 1498$ paras. 1 and 2 (1952). The provisions in question are hased on the statute of July 1, 1918, 40 STAT. 705 (construed in Richmond Screw Anchor Co. v. United States, 275 U.S. 331 (1928)) and on a supplementary act of Oct. 31, 1942, c. 634, §6, 56 STAT. 1014. The latter section was transferred to 28 U.S.C. $\$ 1498$ by Act of Oct. 31, 1951, c. 654, § 50(c), 65 Stat. 727; see 2 U.S. Code Cong. Serv. 1951, 2576, 2593.

128 Act of June 6, 1911, RGB1. 1911 at 243, now $\$ 15$ of the German Patent Act of May 5, 1936, as re-promulgated on July 22, 1953, BGB1. 1953 at 627. For the judicial construction

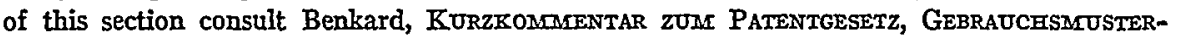
gesetz UNd Patentanwattgesetz 216 (1954); see also Riesenfeld, The New United States Patent Act in the Light of Comparative Lavo I, 102 U. PA. L. Rev. 291, 321 (1954).

129 Information obtained in the German Patent Office in Munich by the author. For the period between 1911 and 1920 no complete data are available because of the destruction of the files. 


\section{Compensatory and Appreciatory Awards}

As mentioned before, the Act of 1954 retains the policy of establishing a system of administrative compensatory or appreciatory awards to be handled by a Patent Compensation Board designated by the Commission. The central statutory provision is section $157^{130}$ and is implemented by Regulations, 10 C.F.R. Part 80, as amended on June 7, 1955. According to the present law the Board considers four types of applications: ${ }^{131}$ (1) for just compensation for any patent revoked in whole or in part by virtue of section 151(a) and (b), rendering inventions useful in the utilization of special nuclear materials or atomic energy to that extent non-patentable; (2) for just compensation for government communication to foreign nations of restricted data based upon a patent application belonging to an owner other than the United States; ${ }^{132}$ (3) for determination of a reasonable royalty fee for compulsory licenses imposed either under section 153 because of the primary importance of the invention and the need for such licensing, or under section 158 because of antitrust law violations; (4) for making any invention or discovery useful in the production or utilization of special nuclear material or atomic energy without being entitled to compensation or royalty therefor under the act. In addition the Board may also grant incentive awards for especially meritorious contributions to the development, use and control of atomic energy without formal application upon recommendation by the General Advisory Committee and with approval of the President ${ }^{133}$ - the so-called "Fermi Prize."

Since in the atomic energy field the determination of what constitutes a reasonable royalty fee for a compulsory license or just compensation for total or partial revocation of an issued patent is by no means obvious, especially in view of the large share of government support in the development and the rapid advance of the technology in this area, the statute spells out a number of factors and considerations to be taken into account. ${ }^{135}$ It would seem, however, that the practical applicability of these standards for the two purposes indicated will be slight, since the better part of the life of the patents which might lave been revoked by the 1946 legislation has now

13068 STaT. 947 (1954), 42 U.S.C. \$ 2187 (Supp. IV 1957).

131 10 C.F.R. \$ 80.10 (Supp. 1957).

132 Pursuant to 42 U.S.C.A. \$ 2223 (Supp. 1957).

13368 STAT. 947 (1954), 42 U.S.C. $\$ 2187$ (b) (3), 2d sentence (Supp. IV 1957).

134 AEC, Seventeenth Semmannual Report 38 (1955).

13568 STAT. 947 (1954), 42 U.S.C. $\$ 2187$ (c) (1) and (2) (Supp. IV 1957). It would seem that the special reference to "any defense, general or special, that might be pleaded by a defendant in an action for infringement" is superfluous. A similar phrase contained in the former statute circumscribing government liability for unlicensed use of patents was deleted upon its transfer into the new Judicial Code of 1948, 62 STAT. 941 (1948), 28 U.S.C. §1498 (1952); see Reviser's note to that section. 
expired and the prospects for compulsory licenses, other than as the result of an intentional violation of the antitrust laws, are not impressive.

On the other liand, it is worth noting that the same factors also control the grants of awards which are provided for persons making any invention or discovery useful in the production or utilization of special nuclear material or atomic energy "who are not entitled to compensation or a royalty therefor under the Act."136 While the latter authorization makes it possible to reward the otherwise unprotected inventors in the still un-patentable atomic weapons field, the scope of this power is by no means restricted to that area. Rather it permits pecuniary awards to meritorious inventors making contributions to any sector of the entire technology pertaining to the utilization of atomic energy, regardless of patentability, so long as they are not eligible for other types of pecuniary benefits under the act. The legislative history of the act seems to show that this system of merit awards was not designed merely as a substitute for patentability in regard to the excluded subject matter as under the 1946 Act, ${ }^{137}$ but was intended as an additional stimulus for inventive activity in a broad sector of technology deemed to be of crucial importance. ${ }^{138}$ In the light of such congressional policy it seems to be a practice of dubious wisdom, if not questionable validity, that the AEC adamantly insists on inserting waivers of all claims for pecuniary awards under the act in its patent contract clauses. ${ }^{139}$ The individual contractor who himself has to forego full patent rights under the patent clauses-if not under section 152-will have little interest in, or miglit otherwise be incapable of, establishing incentive awards for his personnel. Congress appears to have spoken in the atomic energy field although the general subject of incentive awards for private inventors outside of, and in addition to, the patent system is still an issue awaiting final determination. ${ }^{140}$

13668 StaT. 947 (1954), 42 U.S.C. \$ 2187 (b) (3), first sentence (Supp. IV 1957) (emphasis added).

137 An award of this type was granted in Application of McClellan, 91 U.S.P.Q. 278 (1951), CCH AtoMr. EN. Rep. I 3154, and reserved in Application of Schulz, 94 U.S.P.Q. 124, CCH Atom. EN. REP. $\int 3155$ (1952).

138 The same conclusions are reached by Boskey, Some Patent Aspects of Atomic Power Development, 21 LaW \& Contemr. Prob. 113, 119 (1956).

130 See the text quoted note 102 supra.

140 Legislation aiming at the provision of awards for inventive contributions by persons other than government employees has been before the Congress since 1952 when Representative Celler introduced H.R. 7316, 82d Cong., 2d Sess., to that effect. The bill never went beyond the committee stage and its successor in the $83 \mathrm{~d}$ Congress lad no better fate. In the 84th Congress, 1st Sess., H.R. 2383 was introduced for the same purpose and, after extensive hearings and favorable report from the Judiciary Committee, passed the House on July 30, 1955. The Senate, however, took no action. In the 85 th Congress Representative Celler resumed his efforts with the introduction of H.R. 103, 85th Cong., 1st Sess., wlicli was again reported favorably by the Committee on the Judiciary, H.R. REP. No. 148, 85th Cong., 1st Sess. (1957) (with 


\section{Special Safeguards against Improper Acquisition and Use of Patents}

Because of the shift from a system of secrecy and government monopoly to a regime of open competition and private enterprise, during the turbulent gestation of the legislation it was felt in some congressional quarters that some additional safeguards regarding acquisition and use of patents needed to be written into the act in order to forestall the possibility that someone might reap undue advantages from a technology so largely developed with public funds.

(a) Definition of prior art. Section $155^{141}$ specifies that "in connection with applications for patents covered by this Chapter, the fact that the invention or discovery was known or used before shall be a bar to the patenting of such invention or discovery even though such prior knowledge or use was under secrecy within the atomic energy program of the United States." According to an express provision in the general patent law of the United States a person is not entitled to a patent if "the invention was known or used by others in this country ... before the invention thereof by the applicant for patent."142 But, although equivalent language has formed part of the controlling statutes at least since the patent act of $1836,{ }^{143}$ it cannot be said that the exact meaning of the phrase "known or used by others" had become completely clear and fixed. To be sure, in Gayler v. Wilder, ${ }^{144}$ the early leading case in point, Chief Justice Taney, speaking for the majority of the court, had taken the position that the words in question were not to be taken in their literal or absolute sense,

legislative history at 7). It was placed on the Consent Calendar, but upon objection stricken therefrom on April 1, 1957. On June 27, 1957, Representative Nimtz re-introduced an identical bill as H.R. 8420, which was not acted upon before the adjournment on August 30, 1957. The proposed act is expressly intended "to stimulate private enterprise by encouraging private and Government exploitation of inventions and inventive contributions made by cmployces of Government contractors," H.R. REP. No. 148, 85th Cong., 1st Sess. 9 (1957), and to apply to inventive contributions "whether or not patented, unpatented or unpatentable."

14168 STAT. 947 (1954), 42 U.S.C. \$2185 (Supp. IV 1957).

14229 STAT. 692 (1897), 35 U.S.C. $\$ 102 \mathrm{a}$ (1952).

143 Section 6 of the patent act of 1836 predicated the right of an inventor to a patent on the condition that the subject matter claimed was "not known or used by others before his ... discovery or invention thereof." 5 STar. 119, c. $357 \$ 6$ (1836). Already the first American patent statute of 1790 had tersely specified that the purported invention was "not before known or used." 1 STAT. 109, c. $7 \& 1$ (1790); but the second law of 1793 had given a somewhat more complex regulation. On the one hand that act required that the invention for which a patent was applied was "not known or used before the application"; on the other hand, it recognized that it was a valid defense against an action on a patent "that the thing, thus secured by patent, was not originally discovered by the patentee, but had been in use . . . anterior to the supposed discovery of the patentee..." 1 STAT. 319, 322, c.11, $\$ \$ 1$ and 6 (1793) (emphasis added). For a construction and reconciliation of these clauses see especially Pennock v. Dialogue, 27 U.S. (2 Pet.) 1 (1829); Shaw v. Cooper, 32 U.S. (7 Pet.) 292 (1833); cf. Reed v. Cutter, 20 Fed. Cas. No. 11,645 (C.C.D. Mass. 1841).

14451 U.S. (10 How.) 476 (1850). 
but had to be construed in the light of the overall statutory policies and objectives. Accordingly he concluded "that by knowledge and use the legislature meant knowledge and use existing in a manner accessible to the public. ${ }^{3145}$ But his views had prompted impassioned dissents by some members of the tribunal ${ }^{140}$ and, moreover, were questioned, at least to some extent, in a subsequent leading case. ${ }^{147}$ As a result, the problem of whether secret development and use of an invention may constitute anticipation barring a subsequent invention has remained in an unsettled and unsatisfactory state althougl modern text-writers have relied on the dictum of Gayler v. Wilder with apparent approval. ${ }^{148}$ Accordingly, a specific clarification of the subject with respect to patents relating to the production and utilization of atomic energy could justly seem desirable, especially in view of the previous far-reaching secrecy of the atomic energy program in the United States.

Actually, the section in question has been bitterly attacked by such an eminent authority in the field as former Commissioner of Patents Casper Ooms as an unnecessary and unwarranted departure from established principles of American patent law. ${ }^{148}$ But it would seem that the learned critic is not by far on as firm a ground as lie asserts to be, and that a good deal can be said in defense of the policy of the act. Unfortunately, however, the draftsmanship of section 155 is not impeccable; especially the reference to "before" without clearly stating whether the time of the subsequent "invention" or merely of the application is intended might produce unnecessary confusion. Greater harmony with 35 United States Code, section 102(a) would be preferable. It also has been suggested that the bar of the act is too stringent and that prior knowledge or use in connection with the atomic energy program should be anticipatory only if described in a paper published by the Technical Information Service of the Commission; ${ }^{150}$ but again it appears to be debatable whether such restriction is really beneficial.

(b) Monopolistic misuse of patents. Section 158 of the act ${ }^{151}$ contains a special provision relating to the case in which the owner of any patent for an invention of primary use in the utilization or production of special nuclear material or atomic energy is found by a court of competent juris-

145 Id. at 496 (Emphasis added).

146 Id. at 498 (Justice McLean), 501 (Justice Daniel).

147 Coffin v. Ogden, 85 U.S. (18 Wall.) 120, 125 (1873).

148 Walker, Patents $\$ 60$ (Deller ed. 1937); but contrast Curtis, Patents $\$ \$ 86,87$ (4th ed. 1873).

149 Ooms, Some Suggestions Relating to Patent Provisions in Atomic Energy Legislation to Protect the Public Interest, 38 J. PAT. OFF. Soc'y 38, 60 (1956).

150 Cole, Patenting Nuclear Developments, 13 Nocueonics No. 4, 31,34 (1955). Accordingly an amendment inserting a proviso to that effect in $\$ 155$ of the act has been proposed in H.R. 600, 85th Cong., 1st Sess. $\$ 3$ and H.R. 5694, 85th Cong., 1st Sess. \& 14 (1957). See Zimmerman, Patents-Proposed Legislation on Section 155 of the Atomic Energy Act of 1954, 26 GEO. WASH. L. REv. 328 (1958).

15168 STaT. 947 (1954), 42 U.S.C. $\$ 2188$ (Supp. IV 1957). 
diction to have intentionally used such patent in a manner so as to violate the federal antitrust laws. In such contingency the court may require the guilty owner to grant licenses to any other licensee of the Commission who demonstrates a need therefor subject to the payment of a reasonable royalty fee. This section which owes its origin to a senatorial afterthought ${ }^{152}$ and its purported improvement by the Conference Committee ${ }^{163}$ actually fulfills no special purpose and is likely to stifle rather than to facilitate the efficient administration of the antitrust laws. Compulsory licensing as a sanction for the employment of patents in antitrust violations has been recognized by the Supreme Court in a long line of adjudications ${ }^{164}$ and the limitations of the statute are only apt to embarrass the government in the pursuit of its consent decree practice and to foreclose the possibility of even more stringent sanctions. ${ }^{155}$ Calling the section merely "unnecessary" as has been done by another commentator ${ }^{156}$ is therefore actually a polite understatement.

\section{II}

\section{NORMAL PATENT LAW AND NUCLEAR TECHNOLOGY}

It has been urged on diverse occasions and from various quarters that full and untrammeled application of the "normal" patent law should be restored to the atomic energy field. ${ }^{157}$ Intrinsically, nuclear technology possesses no different patent aspects than other branches of inventive endeavor. The sole problem peculiar to atomic science seems to concern the patentability of artificial elements and isotopes. The statutory catalogue of patentable subject matter recognizes only "manufacture" and "composition of matter" as the basis for a possible product patent ${ }^{15 s}$ and it has been held that the isolation of a chemical element is not susceptible of

152 See text to note 75 supra.

163 See text to note 78 supra.

154 Besser Mfg. Co. v. United States, 343 U.S. 444, 449 (1952) ; United States v. Gypsum Co., 340 U.S. 76, 93 (1950) ; United States v. National Lead Co., 332 U.S. 319, 335-51 (1947); Hartford-Empire Co. v. United States, 323 U.S. 386, 415-18 (1945), clarified, 324 U.S. 570 (1945).

155 Cf. United States v. General Elec. Co., 115 F. Supp. 835, 843 (D.N.J. 1953), and the discussions provoked by it: Report of the AtTORNEY GeNeral's National Committee to Study the Antitrust Laws 255-59 (1955) ; Diggins, The Patent-Antitrust Problem, 53 Mich. I. REv. 1093, 1115 (1955) ; Note, A Study of Compulsory Licensing and Dedication of Patents as Relief Measures in Antitrust Cases, 24 GEo. WAsH. L. REv. 223 (1955) ; Note, District Contrt Dedication of Patents to Public Use, 54 Colunc. I. REv. 278 (1954) ; Note, Patent, Dedication as Antitrust Remedy: New Light on Hartford-Empire, 63 YaIE L.J. 717 (1954).

150 Ooms, Some Suggestions Relating to Patent Provisions in Atomic Energy Legislation to Protect the Public Interest, 38 J. Par. OFF. Soc'y 38, 61 (1956).

157 See, e.g., Workshops on Legal Probrems of Atomic Enercy, U. of Mich. LaW SCHOOL 88 (1956). 
product claims ${ }^{159}$ under either of these two concepts. But it could be argued convincingly that the thrust of this rule does not apply to new elements or element types which do not exist on earth and are entirely the result of man's ingenuity. As the subject was discussed not long ago with lucidity and completeness by Mr. Dunlavey, ${ }^{160}$ reference to his exposition may suffice. Patent applications covering such matters are usually under secrecy orders. Consequently the attitude of the Patent Office is unknown to the author.

Actually the special treatment patent-wise of nuclear inventions is dictated by policy considerations predicated on four different though interrelated factors: (1) the current state of nuclear technology is, in the main, the result of the expenditure of huge amounts of public funds; (2) even in times to come vast sums of public funds, in addition to private resources, will have to be spent in order to assure the necessary pace of development; (3) control of atomic information, at least in some respects, is required by the demands of national security; (4) a central government agency is needed as an information clearing house in order to save wasteful duplications of efforts, concomitant with a completely private enterprise system.

Sober reflection cannot but lead to the conclusion that the effects of the first of these indicated four factors must cease to operate as time progresses and the results of privately financed research and development add to the advance of atomic technology. The remaining three reasons apply, perhaps with variations in degree, also to other fields of scientific and experimental inquiry. The political and social realities of our day have forced the federal government, acting through thirty-five or so departments or agencies, to assume financial responsibility for more than half of the total national outlay for research and development. ${ }^{181}$ Since a large share of this activity is carried out by private industry or research institutions under contracts or grants, the attendant allocation of patent rights through appropriate clauses has become a matter of vital concern to the public. There seem to be no cogent reasons why the atomic energy field should be singled out for subjecting government contractors to a wholesale deprivation of patent rights regardless of the modality of their contributions such as that prescribed by section 152 of the act, or to particularly exacting patent clauses. It appears to be high time that the whole field of patent clauses for government contractors be carefully reviewed and made the subject of a uniform

\footnotetext{
15866 STAT. 101, 35 U.S.C. 101 (1952).

159 General Elec. Co. v. De Forest Radio Co., 28 F.2d 641 (3d Cir. 1928).

160 Note, Can Artificially Created Isotopes of Chemical Elements Be Patented? 42 CatrF. L. REv. 676 (1954).

${ }^{101}$ Cf. Honey, Federal Government Organization and Programs for Research and Development-an Overview, 17 FEd. BAR J. 216 (1957); Colman, Small Business and Research and Development, 17 FED. BAR J. 285, 286 (1957).
} 
overall legislative or executive policy directive. Only thus can the American patent system be kept free from unwarranted corrosion.

Unquestionably some of the most felt ${ }^{102}$ difficulties in, and limitations on, the exercise of normal patent rights stem from the secrecy regime governing atomic energy information. The owner of inventions in the nuclear field finds himself in front of a double-barreled gun, viz., the secrecy provisions both of the general patent law and of the Atomic Energy Act.

Involuntary ${ }^{163}$ secrecy of patent applications and consequent withholding of the grant of patents thereon was first introduced into the American patent law by a special statute of $1917^{164}$ as a war-time measure. Shortly before the entry of the United States into World War II the power to issue secrecy orders was extended to peacetime for a period of two years ${ }^{165}$ and supplemented by an amendatory act barring patent applications abroad except by special license and providing more effective sanctions. ${ }^{100}$ After the outbreak of World War II, the regime was continued for the duration. ${ }^{167}$ In 1952, the Invention Secrecy Act of $1951^{168}$ recast the whole law pertaining to secrecy orders relating to inventions and placed it on a permanent basis. The codification of the patent law which took place during the same year transferred this regulation, with slight modifications, into the general patent law. ${ }^{169}$ Under the current provisions, inventions in which the government has a property interest ${ }^{170}$ as well as wholly privately-owned patent applications ${ }^{171}$ may be placed under secrecy orders in the interest of the national security and the grant of the patent withheld, ${ }^{172}$ such order barring the filing of foreign patent application except upon authorization by a license granted with the concurrence of the head of the departments or the chief officers of the agencies who requested the secrecy order. ${ }^{173}$ Individuals damaged by the secrecy order are entitled to compensation. ${ }^{174}$

In addition, the Atomic Energy Act provides that all data concerning

${ }^{162}$ See the revealing testimony of Dr. Starr, General Manager of the Atomics International Division of North American Aviation, Inc., in Development, Growth and State of the Atomic Energy Industry, Hearings Before the Joint Contmittee on Atomic Energy, 85th Cong., 1st Sess. 203, 210-14 (1957).

163 For the possibility given to the inventor by the Patent Act of $1836 \S 8$, of requesting his patent application to be kept in the secret archives of the Patent Office, see Woodbridge v. United States, 263 U.S. 50 (1923).

16440 STAT. 394 (1917), 35 U.S.C.A. $\$ 42$ (1929).

16554 STAT. 710 (1940), 35 U.S.C. $\$ 42$ (1940).

16655 StaT. 657 (1941), 35 U.S.C. $\$ \$ 42 \mathrm{a}-42 \mathrm{f}$ (Supp. 1941-1946).

10756 STAT. 370 (1942).

16866 StaT. 3 (1952).

10966 STAT. 792, 805, 815, 35 U.S.C. \$\$ 181-88 (1952).

17066 STAT. 805, 35 U.S.C. § 181, para. 1 (1952).

17166 StaT. 805-06, 35 U.S.C. \$181, paras. 2 and 3 (1952).

17266 STAT. 805-06, 35 U.S.C. $\$ 181$, paras. 1 and 3 (1952).

17366 STAT. 807, 35 U.S.C. $\$ 184$ (1952).

17466 STAT. 806, 35 U.S.C. \$ 183 (1952). 
(1) the design, manufacture or utilization of atomic weapons; (2) the production of special nuclear material; or (3) the use of special nuclear material in the production of energy is "restricted data"175 and, as such, "born classified" and subject to the information control by the Atomic Energy Commission. ${ }^{176}$

The interrelation of the secrecy provisions of the patent law and the Atomic Energy Act is unfortunately quite confusing. ${ }^{177}$ Where the AEC asserts the domestic title to the invention under section 152 of the Atomic Energy Act or the governing contract patent clauses and chooses to prosecute the American patent application itself no particular problems arise to that extent. The Commission files the application with Division 70 of the Patent Office-the division in charge of the security laws administrationand transmits simultaneously a request for a secrecy order. ${ }^{178}$ But where the domestic title to the invention remains in a private individual the situation is not so simple. Apparently, the fact that the application contains restricted data does not in itself bar a filing of a patent application with the Security Laws Administration Division of the Patent Office, ${ }^{179}$ provided that the regulations for external transmission of classified materials ${ }^{180}$ are observed and that care is taken that the requisite request for a secrecy order is obtained..$^{181}$ Of course, in such case the grant of the patent will be withheld until declassification and rescission of the secrecy order, the applicant being entitled to compensation under title 35 United States Code section 183 unless waived. ${ }^{183}$

Additional difficulties arise with respect to foreign applications in the

17568 StaT. 922 (1954), as amended, 42 U.S.C. \$ 2014(r) (Supp. IV 1957).

170 See especially Green, Information Control and Atomic Power Development, 21 LAw \& Contearp. Prob. 91 (1956); Green, The Atomic Energy Information Access Permit Program, 25 GEO. WASH. I. REV. 548 (1957).

177 For brief discussions of the situation see also Wiles, The Atomic Energy Act of 1954, Aar. Par. L. Ass'N. Busc. 343 (1957); Mackey, Corporate Patent Practice in the Atomic Field, Axr. Pat. L. Ass's. BuLc. 348, 350 (1957).

178 For the number of secrecy orders on Commission-filed patent applications see communication by the AEC to the Joint Counmittee on Atomic Energy, Development, Growth and State of the Atomic Energy Industry, Hearings Before the Joint Committee on Atomic Energy, 85th Cong., 1st Sess. 305 (1957).

179 It seems safe to assume that the officials of Division 70 are persons "authorized to receive Restricted Data" within the meaning of 68 STaT. 959 (1954), 42 U.S.C. $\$ 2277$ (Supp. IV 1957); see also U.S. Atonic ENERgY ComanIsston, AEC ManUar, \& 9113-0112 (1955).

18010 C.F.R. $\$ \$ 95.32$ and 95.33 (1957).

181 For the number of outstanding secrecy orders on atomic patent applications filed by private industry see the communication by the AEC to the Joint Counmittee, Development, Growth and State of the Atomic Energy Industry, Hearings Before the Joint Committee on Atomic Energy, 85th Cong., 1st Sess. 305 (1957).

182 Unfortunately and, in the opinion of the writer, unjustifiably the AEC insists upon waiver of the righlts under 66 STAT. 806, 35 U.S.C. $§ 183$ (1952), with respect to any invention or discovery made or conceived in the course of, in connection with, or under the terms of an access permit, 10 C.F.R. $\$ 25.24$ (c) (2) (1957). 
classified area. ${ }^{183}$ Except where a bilateral international agreement provides for filing on a classified basis, the domestic inventor is barred from seeking a foreign patent until the information has been formally declassified unless lie can eliminate the restricted data from his disclosure. Furthermore the mechanics of declassification imperil his foreign patent status and the cooperation of the AEC is needed to prevent publication which destroys patentability abroad. ${ }^{184}$ To be sure, the AEC has endeavored to assist domestic inventors in preserving their foreign rights, ${ }^{185}$ but a special provision permitting foreign filing with the license from the AEC just ahead of formal declassification might obviate some of the unnecessary dangers.

\section{CONCLUSTONS}

The foregoing discussion liad the purpose of showing that the patent regime in the atomic energy field suffers from three cardinal defects and requires legislative attention. (1) The special patent provisions of the Atomic Energy Act are to a large extent incongruous, superfluous and productive of unnecessary doubts and complications. (2) The secrecy regime of the act is too stringent and too rigid and requires adaptation to the patent protection of American industry abroad. (3) The patent policies of the Commission as practised in the contract clauses and dictated waivers of statutory rights appear to be too exacting and ought to be harmonized with those of other government departments responsible for research and development.

183 See the discussion of the situation in the testimony by Dr. Starr, Development, Growt/2 and State of the Atomic Energy Indiwstry, Hearings Before the Joint Committee on Atomic Energy, 85th Cong., 1st Sess. 203, 210 (1957); and the communication by the AEC, id. at 300. 184 See the testimony by Dr. Starr, note 183 supra.

${ }^{185}$ See the communication by the AEC, id. at 300 . 